\title{
STRENGTH AND WORKABILITY OF CEMENT MORTAR WITH
} MANUFACTURED SAND

\author{
Praveen Kumar $\mathbf{K}^{1}$, Radhakrishna ${ }^{2}$ \\ ${ }^{1}$ Research Scholar, Department of Civil Engineering, RV College of Engineering, Bangalore-560059 \\ ${ }^{2}$ Associate Dean-PG Studies, Department of Civil engineering, RV College of Engineering, Bangalore-560 059
}

\begin{abstract}
Natural river sand is widely used as fine aggregates in preparation of conventional cement mortar. Due to extraction in excess, natural sand has become a scarce material and it has to be preserved. Manufactured sand (M-sand) has very high potential to replace the natural sand in preparation of cement mortar. This research paper presents a study on replacement of natural sand in cement mortar by $M$-sand at different percentages. Strength and workability characteristics of 1:6 cement mortar using natural sand and M-sand as fine aggregate at various replacement levels were evaluated and compared. The workability of the cement mortar increases with the increase in M-sand content up to certain level, whereas the strength increases with the increase of manufactured sand. Hence $M$-sand can be recommended for the replacement of natural river sand in cement mortar.
\end{abstract}

Keywords: sand, manufactured sand, replacement, workability, strength.

\section{INTRODUCTION}

Conventional cement mortar is a composite material obtained by mixing cement, fine aggregate and water. Aggregates have a significant influence on mechanical as well as rheological properties of cement mortars [1]. Physical properties such as particle size distribution, specific gravity, shape and surface texture markedly influence various properties of mortar in their fresh state. Mineralogical composition, modulus of elasticity, toughness and degree of alteration of aggregates are generally found to affect their properties in the hardened state [2]. Keeping in view the ill effects and ecological imbalances resulting out of removal of sand from river beds, the authorities have banned sand mining. This has led to skyrocketing of cost of natural sand [3]. Under these circumstances search for a suitable alternative material to natural river sand without compromising strength and durability aspects of mortar becomes important to support the infrastructural growth and to save the environment.

Various researchers have conducted experimental studies on cement mortars and reported that M-sand mortar is less workable due to angular shaped particles and rough surface texture when compared to natural river sand. Generally Msand contains high fines, whereas lesser amount of clay and silt. Rock dust is the major component of these fines. The effects of particle texture and shape of fine aggregates are more predominant than effects of coarse aggregates in concrete. Better interlocking of particles can be achieved by using angular shape of fine aggregates, which could lead to improvement in strength of cement concrete [4]. M-sand possesses high angularity and when used in cement concrete produces less workability due to increased surface area. This results in increase of segregation in fresh state due to gap gradation [5]. Dosage of admixtures as per manufacturers recommendations are not much effective in manufactured sand mortars, as in case of mortars with natural sand fine aggregates, which even when used in high dosages, failed to attain the flowability or air content observed in natural sand mortar [6]. Porosity of M-sand cement mortar was found to be higher than that with natural sand whereas the compressive strength of M-sand mortar is higher than that of natural sand mortar [7]. Replacement of natural river sand with crushed limestone sand enhances the long term performance of mortars exposed to chemical solutions [8]. Concrete with manufactured sand shows higher compressive strength when compared to the concrete with natural river sand [9]. Bond strength of concrete with m-sand is more and hence development length of rebar can be reduced, leading to economy in construction [10]. There is no comprehensive study reported on the comparison of flow and workability of mortar with and with different percentages of M-sand. In the present study properties of $\mathrm{M}$ - sand cement mortar is evaluated at various replacement levels for flow and compressive strength.

\subsection{Objectives}

This paper deals with the studies on cement mortar with replacement of fine aggregate by alternate material, M-sand at fresh state as well as hardened state at various replacement levels. The main objectives of present study are

$>$ To determine the mechanical properties of conventional cement mortar with natural river sand.

$>$ To determine the flow properties of mortar with replacement of natural river sand by $\mathrm{M}$ - sand.

$>\quad$ To study the effects of replacement of natural river sand by manufactured sand on strength of cement mortar at various replacement levels at different ages. 


\section{MATERIALS AND METHODOLOGY:}

Ordinary Portland Cement of 53 grade satisfying the requirements of IS 12269-2013 [11] was used in preparation of cement mortar. The properties of cement used are indicated in Table 1.

Table 1: Physical Properties of Cement

\begin{tabular}{|l|l|l|l|}
\hline $\begin{array}{l}\text { SI } \\
\text { No }\end{array}$ & Properties & Findings & $\begin{array}{l}\text { Requirement as per } \\
\text { IS:12269-2013[11] }\end{array}$ \\
\hline 1 & Fineness & $6 \%$ & Not more than 10\% \\
\hline 2 & Soundness & $1 \mathrm{~mm}$ & Not more than 10mm \\
\hline 3 & $\begin{array}{l}\text { Initial } \\
\text { Setting Time }\end{array}$ & $\begin{array}{l}165 \\
\text { Minutes }\end{array}$ & $\begin{array}{l}\text { Not less than 30 } \\
\text { minutes }\end{array}$ \\
\hline 4 & $\begin{array}{l}\text { Final Setting } \\
\text { Time }\end{array}$ & $\begin{array}{l}375 \\
\text { Minutes }\end{array}$ & $\begin{array}{l}\text { Not More than } 600 \\
\text { Minutes }\end{array}$ \\
\hline 5 & $\begin{array}{l}\text { Standard } \\
\text { Consistancy }\end{array}$ & $31 \%$ & -------- \\
\hline 6 & $\begin{array}{l}\text { Specific } \\
\text { Gravity }\end{array}$ & 3.10 & ------- \\
\hline
\end{tabular}

Locally available river sand and manufactured sand were used as fine aggregates. The physical properties of both the aggregates are as shown in Table 2. Both these materials confirm to zone II of IS 383:1970 [12]. Natural river sand contains more round particles and have smooth surface texture whereas M-sand consists of elongated particles and rough surface texture. Tap water was used for mixing and curing of the mortar.
Table 2: Physical properties of Fine aggregates

\begin{tabular}{|l|l|l|l|}
\hline $\begin{array}{l}\text { S1 } \\
\text { No }\end{array}$ & Properties & $\begin{array}{l}\text { Natural } \\
\text { sand }\end{array}$ & $\begin{array}{l}\text { Manufactured } \\
\text { Sand }\end{array}$ \\
\hline 1 & $\begin{array}{l}\text { Specific } \\
\text { gravity }\end{array}$ & 2.60 & 2.62 \\
\hline 2 & $\begin{array}{l}\text { Moisture } \\
\text { Content in \% }\end{array}$ & 0.20 & 0.41 \\
\hline 3 & $\begin{array}{l}\text { Fineness } \\
\text { Modulus }\end{array}$ & 2.9 & 3.45 \\
\hline
\end{tabular}

Conventional Cement mortar was prepared using river sand for different water cement ratios from 0.8 to 1.3 . The properties of fresh mortar were evaluated in each case by conducting flow test. For the water cement ratio of 1 , flow test was repeated by replacing the natural sand by M-sand for the replacement levels of 20, 40, 60, 80 and 100\%. A total of 54 mortar cubes of size $50 \times 50 \times 50 \mathrm{~mm}$ were cast for the study. The cubes were cured at room temperature and tested for compressive strength after 3 days, 7 days and 28 days of curing.

\section{RESULTS AND DISCUSSION}

The results of the flow test on conventional cement mortar using natural sand as fine aggregate are shown in Fig. 1. It can be observed that flow of mortar increases with the w/c till 1 and then decreases. After attaining a flow of $84.58 \%$ at $\mathrm{w} / \mathrm{c}=1$, bleeding was observed in cement mortar. Therefore w/c ratio of 1 was selected for further investigations.

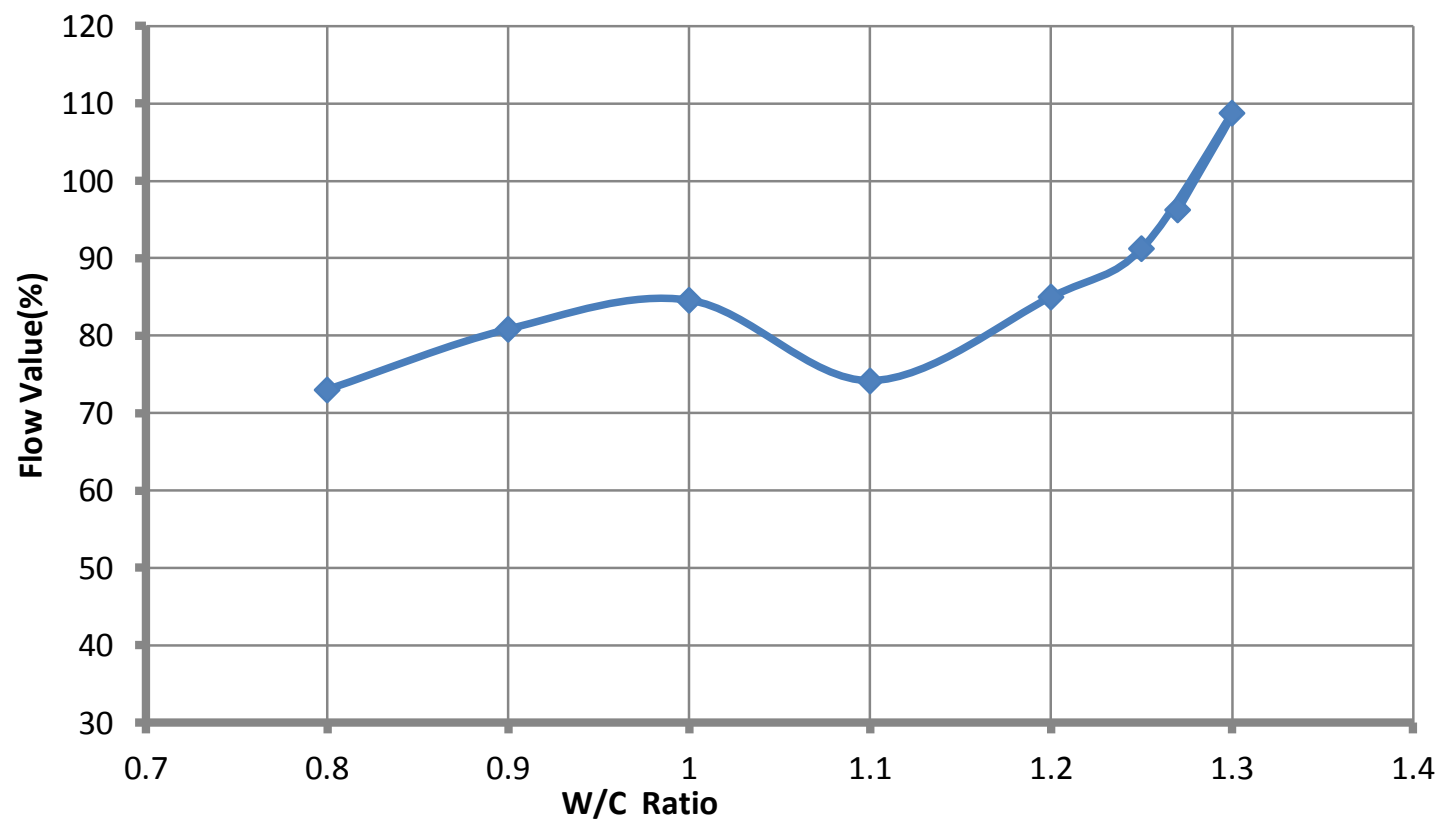

Fig.1: Variation of flow value with w/c Ratio for natural sand cement mortar

The variation of flow values for mortars with natural sand and manufactured sand at various replacement levels are shown in Table 3 and Fig 2. It can be observed that the flow value of mortar with manufactured sand initially increases up to $60 \%$ replacement and then decreases with increase in percentage of manufactured sand. Flow value for M-sand cement mortar is about $25 \%$ less with respect to natural sand cement mortar. 
Table 3: Variation of flow value with for different types of moratrs

\begin{tabular}{|l|l|l|l|}
\hline SI No & Type of mortar(1:6 CM) & Designation & Flow value (\%) \\
\hline 1 & Natural River sand mortar & NS & 75 \\
\hline 2 & Cement Mortar with 20\% M-sand Replacement & $20 \mathrm{MS}$ & 100 \\
\hline 3 & Cement Mortar with 40\% M-sand Replacement & $40 \mathrm{MS}$ & 110 \\
\hline 4 & Cement Mortar with 60\% M-sand Replacement & $60 \mathrm{MS}$ & 115 \\
\hline 5 & Cement Mortar with 80\% M-sand Replacement & $80 \mathrm{MS}$ & 65 \\
\hline 6 & Cement Mortar with 100\% M-sand Replacement & $100 \mathrm{MS}$ & 57.5 \\
\hline
\end{tabular}

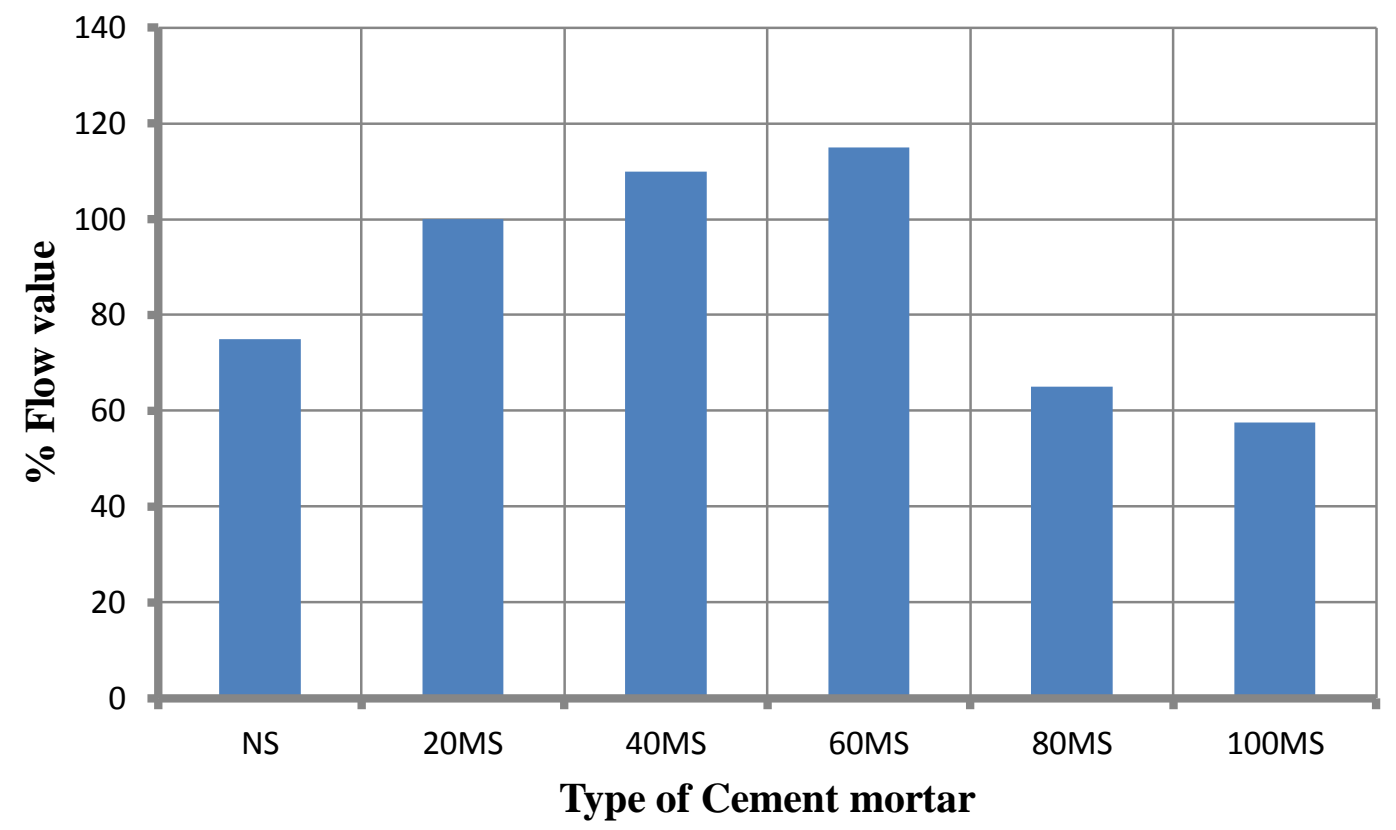

Fig. 2: Variation of flow value with types of mortar

It was observed that the compressive strength of the cement mortar increases with increase in percentage of M-sand replacement. Compressive strengths for different mortar cube specimens at various replacement levels are as shown in Fig. 3.

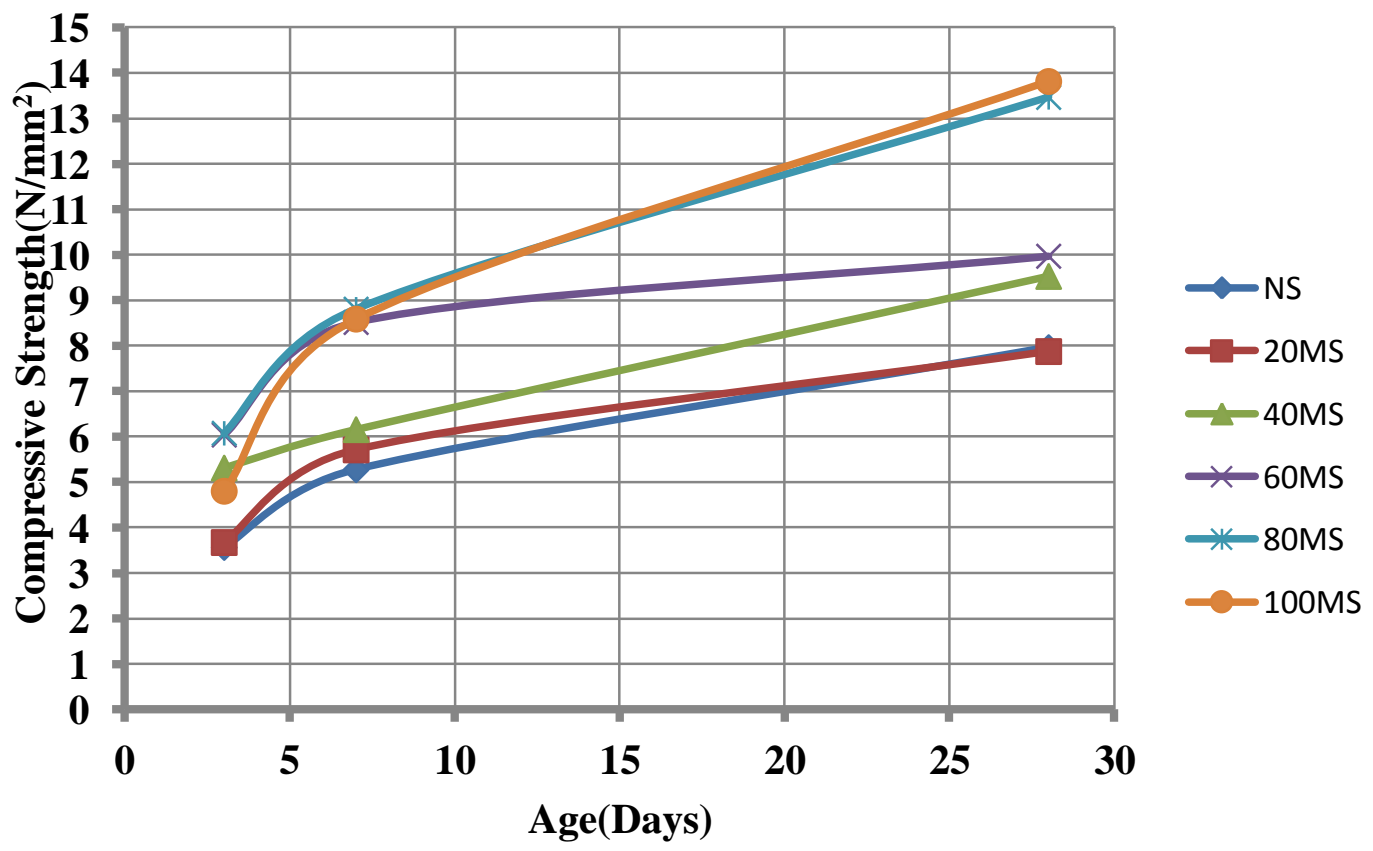

Fig 3: Developemnt of Compressive strength for different types of mortars 
It can be observed that compressive strength incrases with age as expected. The strength of the cement mortar increases with increase in percenatge replacement of $\mathrm{M}$-sand. Compressive strength of cement mortar with $100 \%$ manufactured sand is $73 \%$ more when compared to cement mortar with natural sand as fine aggregate.

\section{CONCLUSION}

Based on the limited experimental results following conclusions can be drawn.

$>$ The workability of mortar increases with partial replacements upto $80 \%$ and reduces upon complete replacement.

> The strength of M-sand mortar is high when compared to natural sand cement mortar at all replacement levels.

$>$ Since workability of $100 \%$ m-sand cement mortar is less, but strength is more, use of admixtures can be made to achieve workability in par with natural sand cement mortar.

$>\quad$ The mortar with M-sand can be recommended for masonry work.

\section{REFERENCES}

[1]. Neville A M, "Properties of Concrete", 3rd Edition, ELBS and Longman, Singapore, (1989).

[2]. Mehta P K ,"Concrete- Structure, Properties and Materials", Prentice Hall-Inc.,Englewood

Cliffs, New Jersey, (1985).

[3]. Nimitha. Vijayaraghavan, Dr.A S Vayal, "Effect of manufactured sand on durability properties of concrete", American journal of engineering Research(AJER), 2(12),437-440, (2013)

[4]. H. Donza, O. Cabrera, E.F. Irassar, High-strength concrete with different fine aggregate, Cement and Concrete Research, 32 (11), 755-1761, (2002)

[5]. Ara A. Jeknavorian,Eric Koehler," Use of Chemical Admixtures to Modify the Rheological Behavior of Cementitious Systems Containing Manufactured Aggregates", NRMCA Concrete Sustainability Conference proceedings, (2010)

[6]. O. A. Cabrera , L. P. Traversa , N. F. Ortega ,"Effect of crushed sand on mortar and concrete rheology", Materiales de Construccion, 61(303), 401-416, (2011).

[7]. Haitao Zhao, Qi Xiao, Donghui Huang, and Shiping Zhang "Influence of Pore Structure on Compressive Strength of Cement Mortar" The Scientific World Journal, 1(12),(2014).

[8]. M. Bederina, Z. Makhloufi, A. Bounoua, T. Bouziani, M. Queneudec, "Effect of partial and total replacement of siliceous river sand with limestone crushed sand on the durability of mortars exposed to chemical solutions", Journal of Construction and Building Materials, Vol. 47, 2013,146-158.

[9]. Nimitha Vijayaraghavan, A S Wayal ,"Effects of manufactured sand on compressive strength and workability of concrete", International. journal of structural \& civil engineering research, 2(4),2013.
[10]. Sureshbabu N., Job Thomas, "Bond characteristic of rebar in concrete with manufactured sand as fine aggregate", American Journal of Engineering Research (AJER), Vol 1,2013, 54-58.

[11]. IS:12269-2013," Ordinary portland cement,53 grade - specification", Bureau of Indian standards, New Delhi, India.

[12]. IS 383-1970(2002)," Specifications for coarse and fine aggregates from natural sources for concrete". 